\title{
Population and development beyond the first demographic transition: a focus on the experience of East and Southeast Asian countries*
}

\author{
Gavin W. Jones**
}

\begin{abstract}
This paper covers a wide scope, focusing on some trends in East and Southeast Asia that may be of interest to Latin America. The first demographic transition has essentially been completed in both regions. The issue is what should now be the focus of our consideration of population and development? East Asian countries are now stressing issues of ultra-low fertility, and policies to raise fertility. They are not comfortable with the prospect of making up future deficits through international migration. The paper also deals briefly with studies of dynamics of change in mega-urban regions, and argues that comparative studies on Latin America and Asia could be valuable. Issues of poverty, development, and equity are then addressed, with particular emphasis on the role of education as a key to equality and development. One dilemma is that in East Asia, the generally commendable obsession with education is one factor making for very low levels of fertility. Finally, the paper touches on population and environmental issues.
\end{abstract}

Keywords: Asia. Fertility. Development. Equity. Education.

\section{Introduction}

The past 50 years have seen the most dramatic changes in the world's population ever recorded in any 50-year period in human history. A small vignette illustrates the changes that have taken place. In 1968, Thailand's population policy focused particularly on the need to lower fertility rates from their high levels (TFR of around 6). In 2011, just 43 years later, a UNFPA-sponsored study on population and development issues in Thailand recommended consideration of policies to help prevent TFR falling below its current level of 1.5 .

As population growth rates slowed, population disappeared from the radar screen of the international development establishment, except in Africa and South Asia. This in no way means that populationdevelopment relationships have ceased to be important, but it does mean that we may need to change the way that we view them.

The present paper will consider some of the population and development issues faced in East and Southeast Asian countries, and whether they may have any relevance to issues faced in Latin America. South Asia will be left out of the picture, as its levels of economic and social development are far behind those of the regions we are comparing. A number of issues will be dealt with, but because of space limitations,

\footnotetext{
${ }^{*}$ Revised version of paper presented at the XV11 Brazilian National Meeting of Population Studies, 20-24 September 2010.

** Professor of the Asia Research Institute, National University of Singapore.
} 
not in the depth they deserve. First, the demographic situation in East and Southeast Asia will be compared with that in Latin America. Ultra-low fertility has become a major issue in East Asia, and the reasons will be discussed, along with issues in countering low fertility through international migration. The discussion will then turn to urbanization, meanings of "development" and "poverty", and the potential role of education in fostering equality and development. Finally, issues of population and environment will be briefly touched on.

\section{Demographic transition in Asia and Latin America}

In the 1960s, the widening gap between birth and death rates resulting from successes in lowering death rates was correctly seen as presaging unprecedented population growth. The aim of lowering fertility rates as fast as possible was firmly accepted by governments of most East, Southeast and South Asian countries. By 1970, not only had India, Pakistan, Singapore, Korea, Sri Lanka, Hong Kong and Taiwan established anti-natalist policies focused especially on family planning programs, but they had more recently been joined by Indonesia, Thailand and the Philippines. (ROBINSON; ROSS, 2007; JONES; LEETE, 2002).

Fertility rates fell faster and to lower levels in East Asian countries than in Latin America. Some in the family planning field have argued that this was the result of slower adoption of family planning programs in Latin America, but it must be borne in mind that levels of economic development in East Asian countries were also higher, and their pace of economic development during the 1970s and 1980s was extremely fast. The fertility experience of Southeast Asian countries varied more, with Thailand going below replacement level fertility in 1990, Vietnam, Indonesia and Myanmar reaching replacement around the present time, and Malaysia, the Philippines, and Cambodia lagging in the fertility transition. There is considerable scope here for challenging a "threshold" approach to onset of fertility declines, or for the speed of decline thereafter, because Vietnam, Indonesia and Myanmar are substantially behind Malaysia and the Philippines in many development indicators. In any case, in relation to Latin America, Oeschli and Kirk (1975) had only limited success in determining threshold levels of indicators at which fertility falls.

What we need to keep in mind is that the relationship between population and development is a two-way street. This was rather ignored by the family planning establishment, until the slogan "development is the best contraceptive" underlined the point at the Bucharest Conference. Attempts to sort out the role of family planning programs in fertility declines are greatly complicated by the fact that significant declines in infant mortality and significant socio-economic changes were taking place in parallel with FP program inputs. All these factors interacted to lower fertility in Asia and Latin America from the high peak of the 1960s.

Table 1 shows some comparisons between Latin American and East and Southeast Asian countries. Some important points seem to emerge. First, population densities are considerably higher in Southeast Asia than in Latin America but not as extreme as those in East Asian countries (including parts of China), or much of South Asia. ${ }^{1}$ This may have influenced the extent to which governments felt a sense of urgency in getting fertility rates down.2

Secondly, we can observe some degree of inverse correlation between levels of economic and social development and fertility rates. But the correlation is far from perfect. Some examples are relatively high fertility in Malaysia and the Philippines;

\footnotetext{
1 Densities in India are 369, Bangladesh 1142; China 141 (but rising to 230 if the peripheral provinces of Tibet, Xinjiang and Inner Mongolia are excluded), Japan 336, South Korea 487.

${ }^{2}$ Two of the Southeast Asian countries with strong family planning programs - Indonesia and Vietnam - did have issues of extreme population density in Java and the Red River delta, respectively.
} 
and remarkably low fertility in Vietnam and Myanmar, relative to their levels of economic and human development.

Thirdly, in general, poorer countries in East and Southeast Asia have lower levels of fertility than countries with equivalent levels of economic development in Latin America. This is clearly the case when we compare China, Thailand and Vietnam with Latin American countries with equivalent per capita income levels. However, nearly all the countries in both regions have now reached low levels of fertility. The only countries with TFR remaining above 3 are Paraguay, Bolivia and Guatemala in LA and Philippines and Cambodia in SE Asia. Of these, only the Philippines is a really populous country.

So the issue so prominent from the 1960 s to 1980 s - the need to get fertility rates down - is now no longer relevant to discussion of issues of population and development in most of Latin America and East and Southeast Asia - unless we accept the view of some environmentalists that populations are already well in excess of sustainable levels. The first demographic transition is essentially over. So - what should now be the focus of our consideration of population and development?

TABLE 1

Comparisons between Latin American and Southeast Asian countries 2005-2010

\begin{tabular}{|c|c|c|c|c|c|c|}
\hline Country & $\begin{array}{l}\text { Population } \\
\text { (2010) }\end{array}$ & $\begin{array}{l}\text { Per capita } \\
\text { GNI (1) } \\
(2007)\end{array}$ & $\begin{array}{c}\text { HDI } \\
(2007)\end{array}$ & $\begin{array}{c}\text { Population } \\
\text { density (2010) } \\
\text { per sq.km. }\end{array}$ & $\%$ urban & $\begin{array}{c}\text { TFR } \\
(2005-2010)\end{array}$ \\
\hline \multicolumn{7}{|c|}{ Latin American Countries } \\
\hline Argentina & 41 & 12,990 & .866 & 15 & 92 & 2.25 \\
\hline Chile & 17 & 12,590 & .878 & 23 & 89 & 1.94 \\
\hline Mexico & 111 & 12,580 & .854 & 57 & 78 & 2.21 \\
\hline Venezuela & 29 & 11,920 & .844 & 32 & 93 & 2.55 \\
\hline Brazil & 195 & 9,370 & .813 & 23 & 87 & 1.90 \\
\hline Cuba & 11 & $?$ & .863 & 101 & 75 & 1.50 \\
\hline Peru & 30 & 7,240 & .806 & 23 & 77 & 2.60 \\
\hline Ecuador & 14 & 7,040 & .806 & 49 & 67 & 2.58 \\
\hline Colombia & 46 & 6,640 & .807 & 41 & 75 & 2.45 \\
\hline Dominican Rep. & 10 & 6,340 & .777 & 211 & 69 & 2.67 \\
\hline Guatemala & 14 & 4,520 & .704 & 132 & 50 & 4.15 \\
\hline Bolivia & 10 & 4,140 & .729 & 9 & 67 & 3.50 \\
\hline Haiti & 10 & 1,150 & .532 & 367 & 52 & 3.55 \\
\hline \multicolumn{7}{|c|}{ East Asian Countries } \\
\hline Japan & 127 & 34,600 & .960 & 336 & 67 & 1.27 \\
\hline South Korea & 49 & 24,750 & .937 & 487 & 83 & 1.22 \\
\hline China & 1,354 & 5,370 & .772 & 141 & 47 & (2) 1.77 \\
\hline \multicolumn{7}{|c|}{ Southeast Asian Countries } \\
\hline Malaysia & 28 & 13,570 & .829 & 85 & 72 & 2.58 \\
\hline Thailand & 68 & 7,880 & .783 & 133 & 34 & 1.81 \\
\hline Philippines & 94 & 3,730 & .751 & 312 & 49 & 3.11 \\
\hline Indonesia & 233 & 3,580 & .734 & 122 & 44 & 2.19 \\
\hline Vietnam & 89 & 2,550 & .725 & 268 & 30 & 2.08 \\
\hline Myanmar & 51 & $?$ & .586 & 75 & 34 & 2.32 \\
\hline Cambodia & 15 & 1,690 & .593 & 83 & 20 & 2.96 \\
\hline
\end{tabular}

Source: United Nations Population Division, 2010; World Bank, World Development Indicators; and UNDP, Human Development Report. (1) Purchasing power parity.

(2) Many Chinese demographers think fertility is lower than this -1.6 is a figure commonly used. Note: This table includes countries with populations exceeding 10 million. 


\section{Ultra-low fertility}

Based on the East Asian situation, one could make the case that the overriding concern from now on will be the issue of ultra-low fertility. In East Asian countries, TFRs have sunk to remarkably low levels, in the range of 1.0 to 1.4 , well below the rates in major Latin American countries (see Table 2). The labour force has already been shrinking for 15 years in Japan and is about to start shrinking in South Korea. Total population is projected by the UN medium projection to decline from 127 million in Japan in 2010 to 102 million in 2050 (and to 90 million in the low projection). Over the same period, South Korea's population is projected to decline from 48.5 million to 44.1 million (and to 38.7 million in the low projection).

How serious are these issues of population decline? Looking at it from one point of view, the projected 2050 population would only bring Japan's population back to the number it had reached in 1968 and South Korea's to its 1993 number. In both cases, many commentators in these countries at that time considered Japan and South Korea to be overpopulated. So why the disquiet about falling back to such levels?

Among demographers, it should not be necessary to belabour the point that the issue is not just one of population size but also one of population structure and population trajectory. The structure of the population would be altered in problematic ways, with the share of the elderly (age 65+) reaching proportions not yet seen in any country of the world (in the case of Japan, rising from an already high 22.6 per cent in 2010 to 37.8 per cent by 2050 ; in South Korea, rising from only 11.0 per cent in 2010 to 34.2 per cent by 2050). ${ }^{3}$ Not only do such increases raise difficult issues about the sustainability of different kinds of income support programs, and care for the disabled and frail elderly, but also there is potential here for inter-generational conflicts.

These age structure changes mean that East Asian countries are reaching the end of the period where they have benefited from the "demographic dividend" when the ratio of potential workers to dependents is high (BLOOM; CANNING; SEVILLA, 2002). However, they have made good use of this dividend period in improving their human capital and achieving high rates of economic growth. Moreover, the prospect of population ageing is not totally negative. The intergenerational transfer literature (e. g. MASON; KINUGASA, 2008) stresses that savings for old age, if invested wisely, have the potential to support economic growth in sustainable ways.

In any case, in contrast to some countries in Europe, where some fertility "recuperation" appears to be taking place as a result of the gap between cohort fertility and period fertility, narrowing once delay of childbearing ends (MYRSKYLA et al., 2009; Goldstein and Jasilioniene, 2009); no such fertility recuperation is in evidence in the East Asian countries, and there are good reasons for arguing that such a recuperation is unlikely in the medium-term future (FREJKA; JONES; SARDON, 2010).

Also, 2050 is not the end of the story. What would happen after 2050? If TFR continued to remain below 1.5 , a continuing downward trajectory of population would be followed, with each generation about one third smaller than the previous generation. Continued over a few generations, the population would shrink dramatically. No country can be expected to welcome such a decline, implying as it does not only issues about elderly support and labour shortages, but also issues in maintaining infrastructure built for a larger population and loss of economic weight and geopolitical status relative to countries where population growth is still occurring.

The causes of these declines in fertility, and what can be done to redress them, can be summarized briefly as follows:

These are countries whose economic success has stunned the world. Their economic success is built on a model of enhanced human capital, with very high

\footnotetext{
${ }^{3}$ By contrast, the proportion aged 65+ in Brazil is projected to increase from 6.9 per cent in 2010 to 22.5. per cent in 2050.
} 
TABLE 2

Total fertility rates, for selected East Asian and Latin American countries 1995-2009

\begin{tabular}{lcccc}
\hline Countries & $\mathbf{1 9 9 5}$ & $\mathbf{2 0 0 0}$ & $\mathbf{2 0 0 5}$ & $\mathbf{2 0 0 9}$ \\
\hline East Asian Countries & & & & 1.37 \\
Japan & 1.42 & 1.36 & 1.25 & 1.14 \\
S. Korea & 1.64 & 1.47 & 1.08 & 1.03 \\
Taiwan & 1.78 & 1.68 & 1.12 & 1.22 \\
Singapore & 1.67 & 1.60 & 1.25 & 1.06 \\
Hong Kong & 1.19 & 1.04 & 0.97 & 2.2 \\
Latin American Countries & & & & 1.9 \\
Argentina & 2.8 & 2.5 & 2.3 & 2.4 \\
Brazil & 2.5 & 2.3 & 2.1 & 2.3 \\
Colombia & 2.9 & 2.7 & 2.5 & 2.5 \\
Mexico & 2.9 & 2.6 & 2.7 & \\
Peru & 3.3 & 2.9 & & \\
\hline
\end{tabular}

Source: East Asian countries: TFR series from national statistical offices; Latin American countries: interpolated from data in United Nations Population Division 2010.

Note: Fertility for Latin American countries roughly interpolated between estimates for 5-year periods in United Nations 2010.

levels of education. Women's education has increased remarkably. In South Korea, the enrollment ratio in senior high school has increased from 24 per cent in 1970 to 56 per cent in 1980, 85 per cent in 1990 and 95 per cent in 2000 - possibly the fastest increase recorded in any country.

Delayed and non-marriage, both voluntary and involuntary, has played an important role (see Figure 1). Involuntary nonmarriage has to do with the changing gender balance in different marriageable age groups as a result of the educational advances just noted, the tradition of hypergamy, and the time taken to get established in a career. Voluntary non-marriage has to do with the diminishing priority given to marriage as a result of various factors noted below, and the lack of appeal to women of the East Asian "marriage package". 4

Women want to be in the workforce to take advantage of their education, and because rising expectations mean that twoincome households are perceived to be necessary. Governments in the region also want them to be in the workforce to boost economic growth rates. But workplaces are family-unfriendly, thus posing great conflicts for women who want to combine a career with raising a family

Other key factors are that children are very costly, in terms of financial, time and emotional investment; men are continuing to hold traditional attitudes toward the gendered division of labour in the household: and appropriate policies to support child-rearing have been lacking until recently, and even now are not comprehensive.

Therefore, policy concern with ways to raise fertility rates hardly seems misplaced in East Asian countries (and in Thailand and Singapore in Southeast Asia).

Looking ahead, should planners in Brazil be anticipating a similar need for policy interventions? Is there really potential for fertility in Brazil to fall as low as in many European and East Asian countries? Possibly so. Fertility in Brazil is already clearly below replacement level and TFR in the Southeast and the South is already down to 1.7 (POTTER et al., 2010).

\footnotetext{
4 This is "the entire package of marital roles for the wife ... including children with their intensive care needs, a heavy household task load, and co-residence with parents-in-law, which is potentially included in the bargain" (BUMPASS et al., 2009, p. 218).
} 
FIGURE 1

Percentages of never-married women, aged 35-39, in East Asian countries - 1970-2010

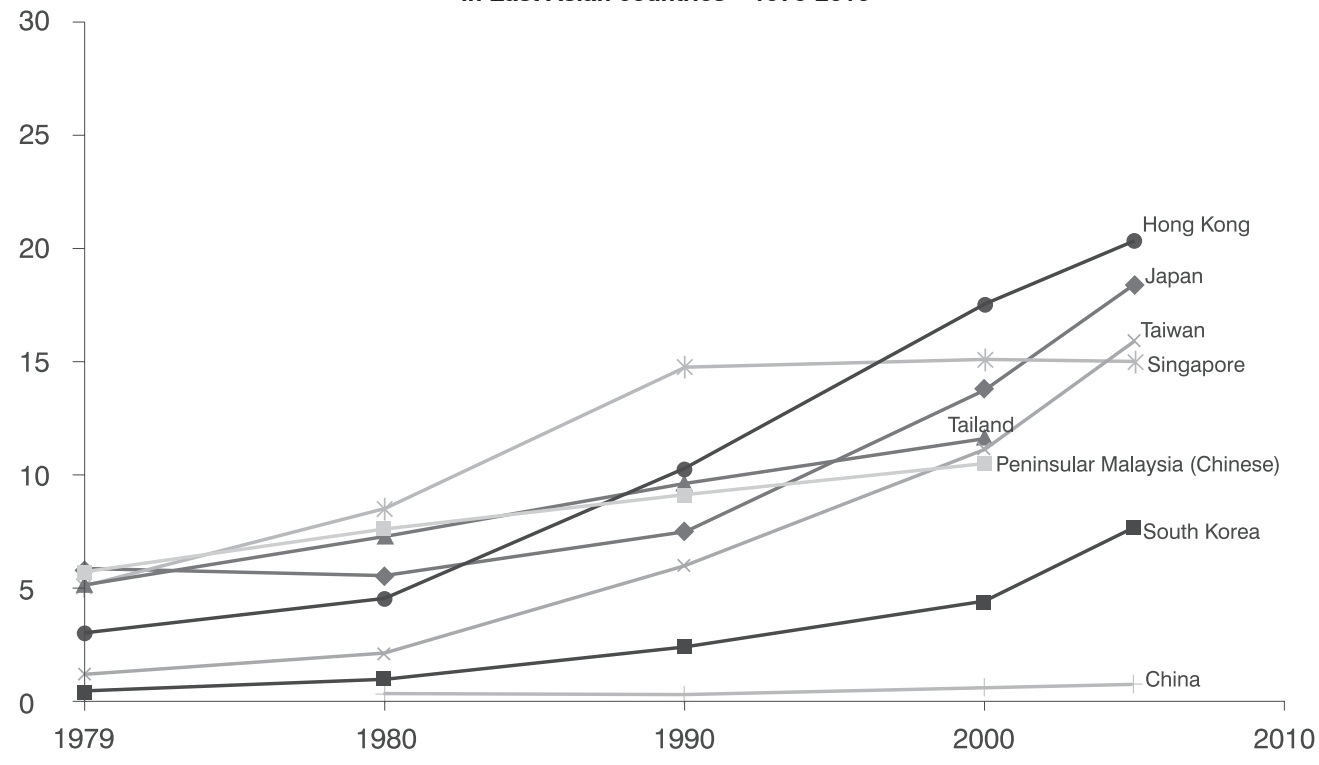

Source: Population censuses of all countries in the figure.

\section{Low fertility and international migration}

As already noted, for East Asian countries, it is hard to see forces that will raise fertility to anywhere near replacement in the foreseeable future. There is always, however, the potential role of migration. The United Nations Population Division (2000) generated a furore in Europe with its study of "replacement migration", showing that the levels of migration required to offset low levels of fertility were unrealistically high. But "unrealistic" in what sense? One issue is whether there is a large enough supply of potential migrants to meet the need. The answer is "yes" - if we are not too concerned about the skill levels, ethnicity and religion of the migrants to be accepted. The other issue is whether the countries concerned would be happy for their populations to be "kept afloat", as it were, by such migration. The answer is "no". The ethnic and religious composition of populations can be dramatically altered by the kinds of migration flows envisaged, and populations in Europe, Japan and South Korea show little appetite for such dramatic changes. Even populations of countries such as Singapore, Australia and the USA, all noted for their ethnically varied populations deeply influenced by migration over long periods, are currently making it clear to their political leaders that they are not happy with continued high levels of immigration.

Coleman (2006) is concerned that the comfortable assumption that immigrants will gradually lose their distinctive identity by converging towards the behaviour and belief patterns of the majority of the population, and creating a "hybrid" population through inter-marriage will not necessarily hold in the case of Europe. For one thing, Muslims predominate among Europe's minorities. Though from diverse national backgrounds, these Muslim populations tend to share a preference for in-group marriage (including finding marriage partners of more traditional bent in the origin country), and their robust identities and religious faith encounter, in the receiving countries, secularized liberal 
societies with weakened feelings of selfesteem and national identity. Coleman (2006, p. 426) also notes that "with larger numbers, populations of foreign origin may feel less need to adapt to local norms, instead becoming more confident in extending their own values, language or laws in a wider society".

The rather unhappy state of affairs in Europe regarding the reception to, and reactions of, immigrants, is no doubt partly the result of the recency of the need to adapt to large immigrant inflows, and partly because of the origins of these inflows, which differ markedly from those to the United States, Australia or Canada, and also differ markedly from the likely origins of any future inflows to countries such as Japan and South Korea, or to the countries of Latin America, for that matter. Brazil certainly falls within the ranks of countries heavily influenced by immigration, and its population is ethnically very mixed, which should make its capacity for accepting migrants greater than that in very homogeneous populations such as that of Japan.

But while some countries are reluctantly accepting unskilled contract workers to meet labour needs, it's a different story with regard to skilled migrants. There is great competition internationally for skilled migrants, and it is less certain that the supply of these will be enough to meet the demands of the many countries selectively encouraging skilled migration.

\section{Urbanization}

One aspect in which Latin America is well ahead of Southeast Asia is in its level of urbanization. Latin America as a whole is
$80 \%$ urban, compared with $42 \%$ in Southeast Asia. Again, levels of economic development appear to explain most of the difference, although not all of it. For example, Thailand is considerably less urbanized than the Latin American countries at much the same level of economic development (though a restrictive definition of urbanization in Thailand explains part of this).

Given that the greatest economic dynamism tends to be in large urban agglomerations (WORLD BANK, 2009), ${ }^{5}$ considerable importance attaches to understanding the dynamics of change in population and employment in such urban agglomerations. I note that very sophisticated analysis has been conducted on Brazilian cities (for example, BAENINGER, 2001; PINTO DA CUNHA, 2001; MARTINE ET AL., 2008; TORRES; ALVES; OLIVEIRA, 2007). There would be some value in collaborations between those working on these issues in Brazilian cities and those conducting related analysis on the megaurban regions of Southeast Asia - Jakarta, Manila, Bangkok and Ho Chi Minh City. One fertile area for collaboration would be in better identifying urban agglomerations and studying the dynamics of change in mega-urban regions. The United Nations Population Division recognizes the problems they face in having to accept whatever urban agglomeration data are supplied by member states. A recent study which attempted to define urban agglomerations according to a simple but comparable set of criteria produced widely different estimates of urban agglomeration data for the largest Southeast Asian cities in 2000 than those used by the United Nations (JONES; DOUGLASS, 2009). 6

\footnotetext{
5 The World Bank's World Development Report 2009, Reshaping Economic Geography, throws out important challenges to some of the accepted wisdom concerning urbanization in the Third World. The processes by which income growth affects urbanization, acting through Engel's Law and technological change, had been much discussed (e.g. Kelley and Williamson, 1984). But the World Bank's report focuses more on the other direction of causation - by which urbanization fosters economic growth. It argues that spatial concentration of economic activity rises with development, and that governments should not resist it by seeking to target investment and policy attention to the lagging areas of their countries. Instead they should adopt a neutral stance on the location of development activities, but make judicious investments in transport and communications which will enable disadvantaged areas to become connected to the centres of growth. "The challenge for government is to allow - even encourage - "unbalanced" economic growth, and yet to ensure inclusive development" (p. 20) through a "well-calibrated blend of institutions, infrastructure and interventions" (p. 6).

6 The figures were: for Manila, 16.24 million, compared with the United Nations figure of 11.63 million; for Jakarta, 17.78 million, compared with the United Nations figure of 9.21 million.
} 
At the same time, although I would strongly argue for the importance of research on the mega-urban regions of Asia, I also agree with the argument that mediumsized and smaller cities - where a much higher percentage of the urban population lives - have been rather neglected by researchers, and that this imbalance needs to be addressed.

\section{What do we mean by development? And what do we mean by poverty?}

Perhaps at this point we need to step back and consider just what we mean by "development" and by "poverty". Population and development is all about lifting people out of poverty. Poverty means having inadequate income to maintain a minimally acceptable quality of life. But is that all it means? There is a need to broaden the concept. Poverty is not only a lack of income and productive assets (fertile land, security of land tenure, housing, irrigation) but also a lack of access to essential social and economic services (such as education, health care, water and sanitation, information, technology and markets) and a lack of power, participation and respect. These dimensions of poverty are interrelated and need to be addressed simultaneously to make a significant impact.

Development in very poor countries is about providing the basic necessities of life - food, clothing and shelter. The MDGs of the United Nations and the World Bank go further, but they are still about meeting basic necessities, viewed a bit more broadly, admittedly - to include universal primary education, improving maternal and child health and combating various diseases. As incomes rise and the bulk of the population rises above subsistence level, it is more possible to focus on other things as well - such as developing a richer cultural life.

If we accept the need for a broader view of both poverty and development, we need to decide what this entails. One approach to poverty is to consider it "disadvantage". Amartya Sen (1999), Martha Nussbaum
(2000) and others have popularized the "capabilities approach", which proposes that there is a set of minimum social, political and material conditions necessary to enable a person to live a 'truly human life'. The notion of social exclusion emphasizes the multidimensional aspects of disadvantage, and focuses particularly on relational issues, such as inadequate social participation, lack of social integration and lack of power.

Let's say we manage to measure "disadvantage" according to some objective criteria. Will this measure then correlate with people's wellbeing?

There has been a ferment of discussion over the best ways of measuring human wellbeing. Economists' concept of Pareto optimality - no one can be made better off (in their own estimation) without making someone worse off (in their own estimation) - is sound in principle, but in practice, better and worse off tends to be defined by consumption levels, meaning that an improvement actually indicates increased pressure on the earth's resources. Because of dissatisfaction with measures of wellbeing that rely on economic output, such as per capita GNP, new measures have sprung up, such as the Gross Happiness Index.

One problem is that when we ask people about their level of life satisfaction, beyond a certain threshold there appears to be little correlation between "self-evaluated happiness" and GDP per capita (EASTERLIN, 1995; DEINER; BISWAS-DEINER, 2002); in other words steady economic growth does not appear to have raised happiness levels in rich countries. At the same time, though, the risk of unhappiness is much higher for poor people in poor countries (DEINER; BISWASDEINER, 2002), thus providing support for efforts to raise incomes and increase equality in these countries. ${ }^{7}$

Do demographers have anything to contribute to this debate? Aside from their long-term interest in the theory of population and development, demographers' methods, including the concern with getting denominators right, cohort analysis, and

\footnotetext{
${ }^{7} \mathrm{~A}$ recent comparative study, based on research in 55 countries, indicates that "high income, individualism, human rights and social equality correlated strongly with each other, and with subjective wellbeing" (DEINER; DEINER; DEINER, 2009).
} 
use of standardization procedures, can contribute to the analysis of disadvantage in many ways. Demography as a discipline is probably also better equipped than others to study many aspects of intra-household differences in well-being that are ignored by the economists' concept of a household utility function, and the effects of different fertility and mortality regimes on such differences in wellbeing. But I think we would have to concede that on the most fundamental issues - what constitutes happiness and what factors contribute to it - we are as much in the dark as others.

\section{Education as a key to equality and development}

Education is a key element in attacking capability deprivation. The key role of education in economic growth has long been accepted, though the case is made in different ways by different authors (e.g. EASTERLIN, 2004; SCHULTZ, 2002; LUTZ, 2009). In my own early research in population and development, I was concerned with the demographic obstacle to the raising of educational enrollment ratios. For poor countries grappling with the consequences of rapid population growth, it was clear that, holding constant the level of commitment of governments to educational expansion, the effect of rapid population growth was to hold down the proportion of the school-age population which could be served by the school system (JONES, 1975). And at the family level, too, larger families had more difficulty in keeping their children in school (KNODEL; WONGSITH, 1991). Economists, such as Schultz (1988), made much the same point with more sophisticated econometric modeling.

But of course, not only demographic factors determine the progress of a nation's education system. As Easterlin (2004, p. 65) has noted, even as late as 1940 , in most of Asia and a substantial part of Latin America, virtually the entire population had little or no exposure to formal education. Colonialism explained part of this lag, but by no means all. Easterlin argues that the spread of the technology of modern economic growth depended on learning potentials and incentives that were linked to the development of formal schooling. For example, the leader in development in Latin America - Argentina - and the leader in economic growth in Asia - Japan - were leaders in education in their regions. He does not accept the argument that educational development may have simply been induced by the process of economic growth itself, rather than being a significant contributor to that process (EASTERLIN, 2004, p. 66).

There are many reasons why education is not always given the role it deserves in development by governments, communities and households. For example, we see in South Asian countries a significant lag in providing equal educational opportunities to girls and boys. This is related to the patriarchal structures in Hinduism and South Asian Islam, which militate against providing education to girls. It is not only that girls are perceived as needing little education because their role is the bearing and rearing of children. It is also that, in more conservative Hindu and Islamic circles, education is seen as endangering the status quo, to the extent that schools for girls are burnt down or forcibly closed, or their principals threatened, in parts of Bangladesh and Pakistan, and groups like the Taliban forbid girls' education.

In relation to the argument that development must be seen in broader terms than merely elimination of dire poverty and raising of per capita income levels, there is much to be said about education as a key vehicle for expanding opportunities, tackling capability deprivation and enabling a broader participation in cultural life. Some of the issues are particularly important, I feel, in large countries with many pockets of rural poverty and isolation, including Brazil and many other countries in Latin America, as well as Indonesia, the Philippines and other countries in Asia.

Unfortunately, equality of opportunity in education remains a distant dream. In Indonesia, for example, 1998 data show that if we compare the proportion of young people aged 16-18 (the ages of upper secondary education) in school according to 
the education level of the head of household, the proportion was about 25 per cent where the household head had none or incomplete primary education, but over 80 per cent if the head had upper secondary or higher education. The poorest schools and least trained teachers tend to be found in the poorest and most isolated areas. Students from these areas have enormous difficulty in moving up through the school system and entering tertiary education. A study in the province of West Timor in Eastern Indonesia found that the key dropout point in the education system is the transition from primary to lower secondary education. But transition from lower secondary school to upper secondary school is also extremely difficult, because of high costs at this level, including both the high cost of school fees and other payments, and the need for children from isolated areas to somehow board in town, because such schools are not available within commuting distance (JONES et al., 1998).

It has been noted that in Latin America, both poverty and non-enrollment are concentrated in poor rural settings where returns to education tend to be low. "Children in impoverished and isolated areas often lack ready access to urban labor markets in which educational credentials directly affect employment. For this reason, the link between education and economic welfare for those remaining outside the school system may be different, on average, than for those already in the school system" (HANNUM; BUCHMAN, 2003, p. 8).

Is government investment in education the solution, or part of the problem?

One would hope that the disadvantages faced by children in city slums and in poor and isolated rural areas would be counteracted, at least to some extent, by the pattern of government spending on education. Unfortunately, often this is not the case, and patterns of educational spending by governments actually exacerbate the prevailing educational inequalities (TAN; MINGAT, 1992). In many countries, the small group of students which reaches postsecondary education receives heavy public subsidization. A high proportion of this group is from white-collar backgrounds, with higher family income levels. In other words, public funds are being used to benefit those who are already advantaged by socioeconomic background. The Indonesian study mentioned above argued that the goals of both equity and efficiency would be furthered if the government adopted a scheme to provide scholarships for bright but poor children to proceed into and through secondary school (JONES et al., 1998).

Lutz et al. (2008) have demonstrated the need to expand secondary education in the interests of economic growth. Not only do we need to expand secondary education, but also to do so in an equitable way, making use of the potential of "bright but poor" children.

\section{Education and ultra-low fertility}

In countries that have progressed economically, parents tend to accord great importance to the educational progress of their children. This is certainly true in East Asian countries. I want to sound one discordant note, however, in assessing what is generally considered to be a commendable trait in parents and indeed in whole societies. In the ultra-low fertility countries of East Asia, although the factors making for low fertility are many (e.g. JONES et al., 2009; JONES, 2007; RETHERFORD; OGAWA; MATSUKURA, 2001), the singleminded emphasis on pushing one's child to succeed in the highly competitive education systems is, I contend, one of the factors that have pushed fertility to unsustainably low levels. For many of those contemplating becoming parents, the high expectations placed on them to raise quality children, and the heavy investment of time and money in arranging coaching and other out-of-school activities become reasons not to have children at all, or to have only one or two.

The economic success achieved in these East Asian countries has much to do with the high quality human capital they have achieved through just such an emphasis on pushing children to strong 
educational performance. The dilemma is that the advanced economy so created will be enjoyed by increasingly fewer citizens and may itself be put at risk by the downward spiral in labour force and (with some delay) in population size. There is great irony in the apparent fact that the very pressures to prioritize economic growth and the factors that can contribute to it long hours of work, involvement of women in the workforce on much the same terms as men, strong pressure on children to perform outstandingly in school, and the extra tuition and coaching that is considered indispensible for reaching this goal - contain the seeds of an inability of the population to replace itself.

\section{Population and environment}

Population-environment interactions is an increasingly important field of study, but an exceedingly complex one. Lutz et al. (2002, p. 5) describe population-environment $(P-E)$ research as a chair with four legs: (1) $P$ (population dynamics), (2) $E$ (environmental dynamics), (3) influences of $P$ on $E, 8$ and (4) influences of $E$ on $P$. Unfortunately, little work has been done on (4). There is a consensus in P-E analysis that

population dynamics impact social, cultural, political, economic and ecologic development, with demographic processes in turn being influenced by social, cultural, economic and ecological conditions. .... But much more is needed. In fact, a reciprocal relationship must be assumed in the sense of circular causality: the effects of the dynamics and the bundle of factors in turn influence the initial causes. Thus, models are needed which can map this circular causality, including all positive and negative feedback loops (HUMMEL; LUX; SHERBININ; ADAMO, 2009, p. 7).

We are far from reaching this goal. For example, current studies of climate change treat population as a given rather than a variable. They commonly cite UN Population Division projections, but these do not claim to predict the future and they rarely if ever make explicit allowance for the impact of environmental change on the components of population change. This methodology is important because any realistic notion of "sustainable" development depends very much on the structure and distribution of populations over time, and these will vary greatly as environmental factors reshape fertility, mortality, migration and settlement, and these dynamic factors will be imprinted on the demographic, economic and social characteristics of the evolving population. Realism demands that such scenarios should strongly register in the assumptions used to project populations over the medium to long term.

These components of demographic change react slowly. Overall national fertility and mortality rates tend to have great inertia built in, and are seldom strongly affected by environmental challenges in the short run. Evidence suggests that the direct influence of the environment on mortality has been declining. The biggest source of environmental deaths remains the poor living conditions and contaminated water and food experienced largely by the poor in developing countries. The conditions for diarrhoea and cholera may worsen as a result of global warming (IPCC, 2007, p. 393 , 471; MCMICHAEL et al., 2004, 2006) while over-rapid urbanisation could worsen the conditions for diseases such as pneumonia and tuberculosis (CALDWELL, 2004)..$^{9}$

Climate change will expose large populations to drought and increased variability of weather. It will reduce agricultural fertility and the productivity of fisheries. It can also increase deaths from sudden events such as tropical cyclones and floods (IPCC, 2007, p. 393). It is expected

\footnotetext{
${ }^{8}$ For a good summary, see Hunter (2000).

9 Climate change is expected to create conditions conducive to the spread of the mosquitoes that spread malaria and dengue (IPCC, 2007, p. 393, 471). Malaria was brought under control in many areas of the world through the use of DDT, but this insecticide is now prohibited or discouraged in most Asian countries. A particular concern has been increasing drug resistance among malaria strains. Nevertheless, in contrast to much of Africa and the Pacific, malaria is largely under control in Asia.
} 
to raise sea levels which will not only endanger productive land but also threaten areas currently safe from sea surges. It will promote heat stress, particularly in large urban areas with concrete and asphalt 'heat islands' (MCMICHAEL et al., 2006). Cardiorespiratory mortality will rise with increases in ground-level ozone (IPCC, 2007, p. 393). Nonetheless governments can prevent some of these deaths. For example, cyclone deaths in Bangladesh have been greatly reduced by the provision of shelters.

Concerns about environmental degradation and climate change may lead to greater acceptance by government and society of the desirability of fertility well below replacement. However, for the reasons I gave earlier, I doubt that governments will see environmental arguments as overriding their other concerns about a declining population.

Of course, the relationship between numbers of people and where they live, on the one hand, and aspects of developmental strategy and management, on the other, are hard to disentangle. A quote from Dr. Salvano Briceno of the UN International Strategy for disaster reduction can illustrate this point. $\mathrm{He}$ pointed to various aggravating factors in the latest (2010) climate catastrophes: China's failure to stem deforestation, contributing to its deadly mudslides; Russia's poor forest management, which feeds fires; and the settling of poor Pakistanis on flood plains and dry riverbeds in the densely populated country. "But the main trend we need to look at is increasing vulnerability, the fact we have more people living in the wrong places, doing the wrong things". (Straits Times, 14/8/2010 "Mid-summer breakdown").

Where environmental factors are likely to have their greatest effect is on migration and the dynamics of settlement change (O'NEIL et. al., 2005, p. 176). Aspects of settlement change such as urbanization and peri-urbanization, intensification of rural settlement, and local displacement are increasingly becoming mechanisms for adaptation to environmental change. Economic development in urban centres and environmental degradation in rural areas may accelerate population shifts from the countryside to cities. Over time, the proportion of urban dwellers with village links steadily declines, thus in some ways increasing the vulnerability of large urban populations.

Despite rapidly growing literature on environmental problems and the impact of population growth on the environment, then, very little has been published on how environmental challenges will shape demographic parameters in the twenty-first century. What has been published on this topic is largely concerned with environmental impact on health and mortality rather than on broader population structure and welfare (O'NEIL et al., 2005; MCMICHAEL et al., $2004,2006)$. A key need is to demonstrate how the impacts of natural disasters, climate change, and environmental degradation can be integrated into population projections to show their effects on fertility, mortality, migration, age and sex structure, and characteristics of individuals.

\section{Conclusions}

The relation between population growth and development will always be a topic of concern, as it has been since the time of Condorcet and Malthus. But the ways the relationships are seen and the particular focus of attention in the debate can and do shift.

The past 50 years have seen the most dramatic changes in both population and economic growth in the history of our planet. The interactions between the two are as relevant an issue as ever.

Many of the issues addressed in this paper have focused on East and Southeast Asia, but I hope that most of them will resonate in various ways with Brazilian demographers. Let me pull together a few of the threads of my argument to address one key issue for East Asia that may have some bearing on discussions of population and development in Brazil. (1) Successful East Asian economies are placed at risk by a shortage of people to continue to power the economies and enjoy their fruits, as a result of ultra-low fertility generated by the very factors that have resulted in the growth of these economies in the first place. (2) In 
these wealthier countries, economic growth is not raising happiness levels. (3) The pattern of economic growth that they have been following is endangering environmental

\section{References}

BAENINGER, R. Migration and urbanization in Sao Paulo: the new scenario. In: HOGAN, D. J. (Ed). Population change in Brazil: contemporary perspectives. Campinas: Population Studies Center (Nepo/Unicamp), 2001.

BLOOM, D. E.; CANNING, D.; SEVILLA, $J$. The demographic dividend: a new perspective on the economic consequences of population change. Santa Monica, Ca: Rand, 2002.

BUMPASS, L. L.; RINDFUSS, R. R.; CHOE, M. K.; TSUYA, N. O. The institutional context of low fertility: the case of Japan. Asian Population Studies, v. 5, n. 3, p. 215-235, 2009.

CALDWELL, B. K. Global environmental change, urbanization and health: the case of rapidly growing dhaka. IHDP Update. International Human Dimensions Programme on Global Environmental Change, 2004, p. 8-9.

COLEMAN, D. Immigration and ethnic change in low-fertility countries: a third demographic transition. Population and Development Review, v. 32, n. 3, p. 401-446, 2006.

DEINER, E.; BISWAS-DEINER, R. Will money increase subjective well-being? Social Indicators Research, v. 57, n. 2, p. 119-169, 2002.

DEINER, E.; DEINER, M.; DEINER, C. Factors predicting the subjective well-being of nations. Culture and Wellbeing, n. 38, p. 43-70, 2009.

EASTERLIN, R. Will raising the incomes of all increase the happiness of all? Journal of Economic Behavior and Organization, n. 27, p. 35-47, 1995.

Why isn't the whole world developed? In: EASTERLIN, R. The reluctant economist. Cambridge: Cambridge University Press, 2004. sustainability. Therefore I think we have grounds for some serious questioning of the model of economic growth that we have been following.

FREJKA, T.; JONES, G. W.; SARDON, J.-P. East Asian childbearing patterns and policy developments. Population and Development Review, v. 36, n. 3, p. 579606, 2010.

GOLDSTEIN, J.; JASILIONIENE, A. The end of lowest-low fertility? In: $26^{\text {th }}$ INTERNATIONAL POPULATION CONFERENCE. Marrakech, Morocco, IUSSP, 2009.

HANNUM, E.; BUCHMANN, C. The consequences of global educational expansion: social science perspectives. Cambridge, Mass: American Academy of Arts and Sciences, 2003.

HUMMEL, D.; LUX, A.; SHERBININ, A. de; ADAMO, S. B. Theoretical and methodological issues in the analysis of population dynamics and supply systems. PERN Background Paper on P-E Theory and Methods, 2009. Available in: <www. populationenvironmentresearch.org $>$.

IPCC - Intergovernmental Panel on Climate Change. Climate change 2007. Impacts, adaptation and vulnerability. Contribution of Working Group II to the Fourth Assessment Report of the IPCC. Cambridge: Cambridge University Press, 2007.

JONES, G. W. Population growth and educational planning in developing nations. New York: Irvington Publishers, 1975.

Delayed marriage and very low fertility in Pacific Asia. Population and Development Review, v. 33, n. 3, p. 453478, 2007.

JONES, G. W.; SUMONO, L. N.; HANDAYANI, $\mathrm{T}$. The expansion of high school education in poor regions: the case of East Nusatenggara. Bulletin of Indonesian Economic Studies, v. 34, n. 3, p. 59-84, 1998.

JONES, G. W.; LEETE, R. Asia's family planning programs as low fertility is attained. 
Studies in Family Planning, v. 33 , n. 1, p. 114-126, 2002.

JONES, G. W.; DOUGLASS, M. Mega-urban regions in Pacific Asia - urban dynamics in a global era. Singapore: NUS Press, 2009.

JONES, G. W.; TAY-STRAUGHAN, P.; CHAN, A. Ultra-low fertility in Pacific Asia: trends, causes and policy issues. London: Routledge, 2009.

KNODEL, J.; WONGSITH, M. Family size and children's education in Thailand: evidence from a national sample. Demography, v. 28, n. 1, p. 119-131, 1991

LUTZ, W. Sola schola et sanitate: human capital as the root cause and priority for international development? Phil. Trans. R. Soc. B., n. 364, p. 3031-3047, 2009.

LUTZ, W.; CUARESMA, J. C.; SANDERSON, W. The demography of educational development and economic growth. Science, n. 319, p. 1047-1048, 2008.

MARTINE, G. et al. (Eds.). The new global frontier: urbanization, poverty and the environment in the $21^{\text {st }}$ century. London: Earthscan, 2008.

MASON, A.; KINUGASA, T. East Asian economic development: two demographic dividends. Journal of Asian Economics, n. 19, p. 389-399, 2008.

MCMICHAEL, A. J. et al. Climate change. In: EZZATI, M.; LOPEZ, A. D.; RODGERS, A.; MATHERS, C. (Eds.). Comparative quantification of health risks: global and regional burden of disease due to selected major risk factors. Geneva: World Health Organization, 2004, p. 1543-1649.

MCMICHAEL, A. J.; WOODRUFF, R.; HALES, S. Climate change and human health: Present and future risks. The Lancet, n. 367, p. 859-69, 2006.

MYRSKYLA, M.; KOHLER, H-P.; BILLARI, F. Advances in development reverse fertility declines. Nature, v. 460, n. 6, p. 741-3, 2009.

NUSSBAUM, M.C. Women and human development: the capabilities approach. Cambridge: Cambridge University Press, 2000.
OESCHLI, F.; KIRK, D. Modernization and the demographic transition in Latin America and the Caribbean. Economic Development and Cultural Change, n. 2, p. 391-419, 1975.

O'NEIL, B. C.; LUTZ, W.; MACKELLAR, L. Population and climate change. Cambridge: Cambridge University Press, 2005.

PINTO DA CUNHA, J. M. Intraregional mobility in the context of migratory changes in Brazil between 1970 and 1991: the case of the Sao Paulo metropolitan region. In: HOGAN, D. J. (Ed.). Population change in Brazil: contemporary perspectives. Campinas: Population Studies Center (Nepo/Unicamp), 2001.

POTTER, J. E.; SCHMERTMANN, C. P.; ASSUNCAO, R. M.; CAVENAGHI, S. M. Mapping the timing, pace and scale of the fertility transition in Brazil. Population and Development Review, v. 36, n. 2, p. 283308, 2010.

RETHERFORD, R.D.; OGAWA, N.; MATSUKURA, $R$. Late marriage and less marriage in Japan. Population and Development Review, v. 27, n. 1, p. 65-102, 2001.

ROBINSON, W. C.; ROSS, J. A. (Eds.). The global family planning revolution. Washington, D.C.: The World Bank, 2007.

SCHULTZ, T. P. Education investments and returns. In: CHENERY, H.; SRINIVASAN, T. N. (Eds.). Handbook of development economics. New York: North-Holland, v. 1, 1998.

Why governments should invest more to educate girls. World Development, n. 30, p. 207-225, 2002.

SEN, A. Development as freedom. New York: Alfred Knopf, 1999.

TAN, J-P.; MINGAT, A. Education in Asia: a comparative study of cost and financing, Washington, D.C.: The World Bank, 1992.

TORRES, H. G.; ALVES, H. P. F.; OLIVIERA, M. A. Sao Paulo peri-urban dynamics: some social causes and environmental consequences. Environment and Urbanization, n. 19, p. 207-223, 2007. 
UNITED NATIONS. Replacement migration: is it a solution to declining and ageing populations? New York: United Nations Population Division, 2000.

World population prospects, as

assessed in 2010. New York: United Nations

Population Division, 2010.
WORLD BANK. World development report

2009: reshaping economic geography. Washington, D.C.: World Bank, 2009.

\section{Resumo}

População e desenvolvimento além da primeira transição demográfica: discussão da experiência de países do Leste e Sudeste da Ásia

Este artigo é bastante abrangente e se concentra em algumas tendências do Leste e Sudeste da Ásia que podem ser de interesse para a América Latina. A primeira transição demográfica foi concluída em essência em ambas as regiões. A questão atual é qual deve ser o foco de nossa atenção em população e desenvolvimento? Atualmente, os países da Ásia Oriental estão enfatizando as questões de fecundidade ultrabaixa e políticas para fomentar a fecundidade. Esses países não se sentem à vontade com a perspectiva de compensar déficits futuros por meio de migração internacional. Este artigo também discute de forma resumida os estudos de dinâmica de mudança em regiões megaurbanas, e defende a ideia de que estudos comparando a América Latina e a Ásia poderiam ser de grande importância. Em seguida, são discutidas as questões da pobreza, desenvolvimento e equidade, com especial ênfase no papel da educação como fator-chave para a equidade e o desenvolvimento. Um dos dilemas é que a obsessão, em geral admirável, da Ásia Oriental com educação é um dos fatores que determinam os índices muito baixos de fecundidade. Por fim, o artigo aborda questões populacionais e ambientais.

Palavras-chave: Ásia. Fecundidade. Desenvolvimento. Equidade. Educação.

\section{Resumen}

Población y desarrollo más allá de la primera transición demográfica: discusión sobre la experiencia de países del Este y Sudeste asiático

Este artículo es bastante englobador, y se concentra en algunas tendencias del Este y Sudeste asiático que pueden resultar de interés para América Latina. La primera transición demográfica concluyó en esencia en ambas regiones. La cuestión actual es cuál debe ser el foco de nuestra atención en población y desarrollo. Actualmente, los países de Asia Oriental están dando énfasis a las cuestiones de fertilidad ultrabaja y políticas para fomentar la fertilidad. Esos países no se sienten a gusto con la perspectiva de compensar déficits futuros a través de la migración internacional. Este artículo también discute de forma resumida los estudios de dinámica de cambios en regiones megaurbanas, y defiende la idea de que estudios comparando América Latina y Asia podrían ser de gran importancia. A continuación, se discuten las cuestiones de pobreza, desarrollo y equidad, con especial énfasis en el papel de la educación como factor clave para la equidad y el desarrollo. Uno de los dilemas es que la obsesión, en general admirable, de Asia Oriental con la educación es uno de los factores que determina los índices tan bajos de fertilidad. Finalmente, el artículo aborda cuestiones poblacionales y ambientales.

Palabras-clave: Asia. Fertilidad. Desarrollo. Equidad. Educación. 
